\title{
Bildung and Temporality in Justin Quinn's Mount Merrion
}

\section{Eóin Flannery}

\section{(2) OpenEdition \\ 1 Journals}

\section{Electronic version}

URL: https://journals.openedition.org/etudesirlandaises/10277

DOI: 10.4000/etudesirlandaises. 10277

ISSN: 2259-8863

\section{Publisher}

Presses universitaires de Caen

\section{Printed version}

Date of publication: 31 December 2020

Number of pages: 163-185

ISBN: 978-2-84133-996-9

ISSN: 0183-973X

\section{Electronic reference}

Eóin Flannery, "Bildung and Temporality in Justin Quinn's Mount Merrion", Études irlandaises [Online], 45-2 | 2020, Online since 31 December 2020, connection on 14 November 2022. URL: http:// journals.openedition.org/etudesirlandaises/10277 ; DOI: https://doi.org/10.4000/etudesirlandaises. 10277

\section{(c) (1) (2)}

Creative Commons - Attribution-NonCommercial-ShareAlike 4.0 International - CC BY-NC-SA 4.0

https://creativecommons.org/licenses/by-nc-sa/4.0/ 


\title{
Bildung and Temporality in Justin Quinn's Mount Merrion
}

\begin{abstract}
The article focuses on the ways in which genre, narrative and time intersect in readings of cultural responses to both the global economic crash of 2008 and the implosion of Ireland's Celtic Tiger debt economy. Justin Quinn's employment of an iteration of the bildungsroman in Mount Merrion (2013) is telling in the context of the demise of the Irish economic "boom", given that it references one of the classic realist narrative forms through which citizen-consumers were hailed and ratified. In this sense, the novel partially furnishes a deeper historical contextualisation of the roots and the development of the political and economic environments that eventuate with the Celtic Tiger "boom". Additionally, with its attention to teleology and its structural affinities to the bildungsroman, Mount Merrion raises questions about competing and interlocking varieties of temporality. In Quinn's employment of the bildungsroman form, and its allegorical and temporal features, we identify youthful characters that defy the allegorical form and temporal trajectories of the generic conventions of the bildungsroman. While Quinn's narrative does not ultimately fashion radical aesthetic or political alternatives to the prevailing neoliberal-capitalist conjuncture, it raises provocative questions regarding the possibilities of imaginative alternatives that are coeval with, and embedded within, dominant narrative forms.
\end{abstract}

Keywords: Celtic Tiger, bildungsroman, narrative time, finance fiction, debt, haunting.

Résumé: L'article porte sur la manière dont le genre, le récit et le temps se croisent dans la lecture des réponses culturelles au crash économique mondial de 2008 et à l'implosion de l'économie de la dette du Tigre celtique irlandais. L'emploi par Justin Quinn d'une itération $d u$ bildungsroman dans Mount Merrion (2013) est révélateur dans le contexte de la fin du "boom» économique irlandais, étant donné qu'il fait référence à l’une des formes narratives réalistes classiques par lesquelles les citoyens-consommateurs ont été salués et ratifiés. En ce sens, le roman fournit en partie une contextualisation historique plus profonde des racines et du développement des environnements politiques et économiques qui ont suivi le "boom" du Tigre celtique. De plus, en s'intéressant à la téléologie et ses affinités structurelles avec le bildungsroman, Mont Merrion soulève des questions sur les variétés de temporalité concurrentes et imbriquées. Dans l'emploi que fait Quinn du genre du bildungsroman et de ses caractéristiques allégoriques et temporelles, nous identifions des personnages jeunes qui défient la forme allégorique et les trajectoires temporelles des conventions génériques $d u$ bildungsroman. Bien que le récit de Quinn ne crée pas en fin de compte des alternatives esthétiques ou politiques radicales à la conjoncture néolibérale-capitaliste dominante, il soulève des questions novatrices concernant les possibilités d'alternatives imaginatives qui sont coévolutives et intégrées aux formes narratives dominantes.

Mots clés: Tigre celtique, bildungsroman, temps du récit, fiction financière, dette, hantise.

Études irlandaises, $\mathrm{n}^{\circ} 45-2,2020$ - p. 163-185 


\section{Time and debt}

As the title indicates, our focus will be on the ways in which genre, narrative and time intersect in readings of cultural responses to both the global economic crash of 2008 and the implosion of Ireland's Celtic Tiger economy. Justin Quinn's employment of an iteration of the bildungsroman in Mount Merrion (2013) ${ }^{1}$ is telling in the context of the demise of the Irish economic "boom", given that it references one of the classic realist narrative forms through which citizen-consumers were hailed and ratified. It is a literary mode that "conventionalized a narrative pattern for participation in the egalitarian imaginary of the new bourgeois nationstate" 2 . And while Quinn's narrative does not ultimately fashion radical aesthetic or political alternatives to the prevailing neoliberal-capitalist conjuncture, it raises provocative questions regarding the possibilities of imaginative alternatives that are coeval with, and embedded within, dominant narrative forms. In this context, the key role of narrative form since the global financial crash is thrown into relief by Richard Dienst in his radical engagement with the politics of debt. As he surveys the post-crash landscape, Dienst concludes that:

The apocalyptic rhetoric, springing from the mouths of revered oracles, had the desired effect: everybody got scared. Bailouts were rammed through, emergency powers were invoked, and a few well-paid heads rolled. Then, as soon as the first burst of panic died down, the rewriting began.

It did not take long before a crowd of explanations, interpretations, and predictions started wrangling over the story line ${ }^{3}$.

Of course, the signal importance of narrative is not confined to the post-crash management of the fall-out, but is fundamental to the ways in which financial and property markets are structured and operate. As Jeffrey C. Alexander makes plain:

Economic actors, whether institutions, markets, states, or individuals, engage in performances that project meanings. Because their decisions about investment depend upon confidence in a bright future, they need an optimistic narrative that structures the moment-to-moment interpretations of the meaning of economic life. It is via interest rates that such narratively structured expectations take a direct and concrete economic form. Interest rates determine investment, but they are themselves a sign and not only a determinant. Interest is a metaphor for confidence in the prudence of economic actors large and small ${ }^{4}$.

1. Justin Quinn, Mount Merrion, Dublin, Penguin, 2013 (page numbers between brackets refer to this edition).

2. Joseph R. Slaughter, "Enabling Fictions and Novel Subjects: The Bildungsroman and International Human Rights Law”, PMLA, vol. 121, no. 5, 2006, p. 1410.

3. Richard Dienst, The Bonds of Debt: Borrowing against the Common Good, London, Verso, 2011, p. 7.

4. Jeffrey C. Alexander, "Market as Narrative and Character", Journal of Cultural Economy, vol. 4, no. 4, 2011, p. 484 . 
In common with a broad school of economic criticism, Alexander's analysis underscores the figurative aspects of finance as it deploys explicitly narratological terminology ${ }^{5}$. Yet, equally, from a material perspective, temperament, desire and agency are impacted upon, indeed guided by, the figurations extant within markets. Consoling and persuasive narratives, then, aid in the perpetuation of consumption and investment, as well as the extension of material inequalities.

In fact, the latter term - "investment" - is a fraction of yet another cornerstone metaphor of prevailing market narratives, and was acutely effective at the zenith of the Celtic Tiger property "boom". Aggregating temporality and spatiality, a powerful figuration during this period was the notion that purchasing a house was a secure "investment in the future". In this respect, it was not alone that choices in the present were limited to immediate effect, but the future became a feature of the narrativisation of the life-cycle of the globalised Irish economic actor. Thus, a semiotics of consumption and investment contours the palate of expectations and choices made available to the contemporary homo economicus ${ }^{6}$. Success, failure, prosperity are the cardinal narrative indices under such an economic value system, and one of the accruals in the Celtic Tiger context is an "affective economy of the New Irishness" 7 . A temporalised sense of national identity displaces what Diane Negra describes as "an earlier set of representational codes that tended to stress emotions such as sentimentality, pathos, nostalgia, volatility and vitality" ${ }^{8}$. Progress, investment, efficiency and consumption were the most publicly touted "values" and "virtues" of the new iterations of "Irishness", and they are sited within temporal regimes that stress a future-oriented telos. Yet what was less commonly advertised was the extent to which indebtedness was an enabling agent of the Celtic Tiger "boom". Though not at the heart of the current discussion, we must remain cognizant of the extent to which the temporality of debt shadowed, and shadows, the economic activities of Celtic Tiger and post-Celtic Tiger Irelands. In short, without Ireland's immersion into the global debt economy, the economic developments of recent decades, tracked in Mount Merrion, would not have been possible. From a literary perspective, our focus on the bildungsroman attends to one form of narrative of progression, but such progression is inalienably linked to the "time of debt". Indebtedness becomes instrumental in the narrative trajectories and potentialities of individual life stories, seemingly offering limitless choice, while, in reality, making a hostage of future narrative choices. Thus, it is important to devote attention to an example of a literary intervention that wrestles with the inextricable links between progress, narrative and finance through a classic narrative form of development and teleology.

5. An indicative list of scholars working on finance and literature would include: Alison Shonkwiler, Annie McClanahan, Paul Crosthwaite, Peter Knight, Nicky Marsh, Leigh Claire La Berge, Arne De Boever, Anna Kornbluh, Joshua Clover and Laura Finch.

6. On homo economicus see Michel Foucault, The Birth of Biopolitics: Lectures at the College de France, 1978-1979, London, Picador, 2010.

7. Diane Negra, "Urban Space, Luxury Retailing and the New Irishness", Cultural Studies, vol. 24, no. 6, 2010, p. 839 .

8. Ibid. 


\section{Bildung and Irish economic modernisation}

In his analysis of Thomas Mann's modernist classic, The Magic Mountain, Russell A. Berman attends to the novel's concern with temporality - both with respect to its formal problematisation of the conventional bildungsroman, as well as its modernist reflections upon the contextual "times" of its genesis. In Berman's estimation, Mann's text:

[...] might also be classified as a Zeitroman in a two-fold sense: it is a novel that - with reference to the immediate past - poses fundamental questions about its own time, and it is a novel thematically and structurally concerned with time and its duplicities. While the Bildungsroman typically took time for granted in order to describe the difficulties of growth, The Magic Mountain explores the character of time itself 9 .

It is not our intention to draw analogies between Quinn's Mount Merrion and a raft of modernist novels - though in selected aspects of its form and content one can identify self-conscious allusions and debts to Mann, as well as to Joyce, to F. Scott Fitzgerald, to Virginia Woolf and to T. S. Eliot. Rather, building upon Berman's references to the ways in which Mann's novel worries over notions of temporality and crisis within a particular narrative form, Quinn's narrative offers an opportunity to think about another literary formal response to the post-Celtic Tiger crisis period in Irish culture and society. Specifically, our discussion will address Mount Merrion in terms of its thematic concern with temporality, and we will consider the ways in which Quinn frames such a thematic preoccupation within the lineage of the bildungsroman - a form that Quinn effectively critiques within the novel. The relevance of bildung and the bildungsroman to critical and creative responses to the Irish economic "boom" are wedded to the notion that Celtic Tiger prosperity was part of the fated narrative of "progress" heralded by the nation's emergence into modernisation from the 1960s onward. As Pieter Vermeulen and Ortwin de Graef detail:

[...] the main selling point of Bildung is that it offers a developmental pattern in which increased self-reflexivity does not come at the expense of self-identity; instead of leading to abysmal alienation, moments of reflexivity are continuously naturalized as part of a plan of self-actualization ${ }^{10}$.

Clearly it is not viable to transplant a well-established, and widely critiqued, narrative form to a limited historical period in a single society, but the teleological pattern characteristic of bildung was evinced by many of the architects and cheerleaders of the Celtic Tiger economy. The stadial progress towards full maturation and,

9. Russell A. Berman, "Modernism and the Bildungsroman: Thomas Mann's Magic Mountain", in The Cambridge Companion to the Modern German Novel, Graham Bartram (ed.), Cambridge, Cambridge University Press, 2004, p. 84-85.

10. Pieter Vermeulen, Ortwin de Graef, "Bildung and the State in the Long Nineteenth Century", Partial Answers, vol. 10, no. 2, 2012, p. 243. 
ultimately, social conformity, loosely evidenced in narratives of bildung clearly echoes in equivalent narratives of emergence regarding Ireland's realisation of its economic potential within the global capitalist conjuncture.

As we have noted, with its attention to teleology and its structural affinities to the bildungsroman, Mount Merrion raises questions about competing and interlocking varieties of temporality. From a generic perspective, the narrative could easily find itself stabled as a form of historical novel regarding the recent history of Irish economic and social development. Quinn's protagonists, Declan and Sinead Boyle, serve as actors and actants in what might be viewed as a newly-minted tale of the blossoming nation-state, as they, individually and collectively, strive for roles in the nation-state narrative. In this sense, the novel partially furnishes a deeper historical contextualisation of the roots and the development of the political and economic environments that eventuate with the Celtic Tiger "boom". Within the wider Boyle family, time and continuity are flagged as significant markers of status and achievement. Declan diverges from his father's expectations that he will follow his example and pursue a legal career, while Declan's son Owen, in turn, veers away from the path envisaged for him by his own father. Thus, the novel primarily charts Declan's emergence as both a political and economic agent of the "new" "pre" and "high"-Celtic Tiger Ireland. While he fails to conform to the "narrative" trajectory ordained by his father, in no way does this detour offer a compelling challenge to the normative fabric of his social milieu. Declan Boyle's alternative bildung is merely a re-imagined renewal of the status quo, and it is never a revolutionary rejection of his social and economic inheritance. Quinn's concern with national and international, political and economic temporalities also manifests in the geographies of the narrative, and the ways in which time becomes spatialized ${ }^{11}$. In a familiar suite of spatial figurations, the diverse geographies that punctuate Mount Merrion - Dublin, south Dublin, the west of Ireland, the German Democratic Republic, Berlin, Prague, Yugoslavia, and New York - inter alia assume ideological significance, as well as representing alternate forms of temporality. Further underscoring the novel's concern with narration and temporality, the story of the Boyle family's role within the recent history of modern Ireland is delivered episodically within a narrative framework that works its way through seven chapters set in six different time periods: 1959; 1968; 1974-1975; 1987; 1995; and 2002. In a sense we are offered an intimate, yet generational, backstory to the emergence and denouement of the Celtic Tiger economy. And it is a story that gestures to the national and the international informants and architects of the latter-day economic "boom" in Ireland. On the one hand, the episodic structure of Mount Merrion seems to afford degrees of continuity and teleological momentum to the stories of personal and national progress showcased therein. But the fragmentation of such episodic narration is equally suggestive of the intra-familial and cross-generational discord that clearly subtends Boyle family relations.

11. Useful guides in these areas are: Robert F. Tally, Spatiality, London - New York, Routledge, 2013; and Russell West-Pavlov, Temporalities, London - New York, Routledge, 2013. 
We first encounter Declan Boyle in the "New Hospital" in 1959 as he recovers in Ardnabrayba, his paternal home-place, and immediately Quinn flags the novel's core concerns with progress, novelty and temporality. As Ireland stands on the precipice of social and economic modernisation, one of the future facilitators of its continued progress lies prone in a ward of the newly-built county hospital in the west of Ireland:

The county hospital was only a few months old. The nuns and doctors still got lost in its corridors and ended up asking colleagues for directions in loud, humorous tones. The nuns especially seemed to doubt the very feasibility of the building. For them, the place still had the air of an experiment, the ambition of which was too outrageous to succeed. They would not have been surprised to be sent back to the smaller healthauthority clinics after a year's trial, leaving the new hospital to rust like an impressive wreck on the wild rocks of the western coast. (p. 3)

In this keynote opening paragraph, the narrative's attention to temporality, as well as discrepant temperamental responses to the virtues and possibilities of linear temporal progress, are thrown into sharp relief. The hospital is an early and decisive figurative incarnation of the emergent prioritisation of economic and social progress. Yet the co-location of secular and religious reactions to the new building is revealing. While not a crude juxtaposition of "tradition" and "modernity", nevertheless they furnish an initial instance of Quinn's interest in the multiple attitudes to accelerated, linear temporal trajectories. This tension exposes the narrative's offering of alternative perspectives on the temporal and narrative options available to Irish society. Equally, and in a similar vein, the architectural statement of modernising intent is sited in the west of Ireland, a location more likely to be figured in terms of antecedent or backward temporalities. Again, at this early juncture, and as we shall track elsewhere, Quinn's narrative disabuses the reader of any dichotomous acceptance of a unidirectional temporal logic or progressivist chronological simplicities. In this respect, Quinn draws upon, and seems to refute, historical notions regarding the temporalisation of spaces along competing hierarchical lines - itself more often associated with colonialism. Disorientation and ambition culminate here in the resonant, and at this point almost familiar, similative reference to the crumbling yet striking edificial remainder of this modern monument. But it is not just the resolution of the paragraph in this quasi-Romantic figuration that is germane to our argument, the sentence in which the simile is situated changes tense from the present to the past conditional. The certainty of the present tense is replaced by the elusiveness of the past conditional, in this case by the articulation of an arresting, Hopkins-esque image delivered in conditional rather than definite terms. This early grammatical shift is a further indice of the narrative's critical complication of the easy certainties of linear temporal progress, as they are enshrined in the narratives of capitalist progress.

Just as Declan Boyle enters the narrative from the confines of a hospital bed in 1959, Quinn closes Mount Merrion in 2002 with Declan again recumbent in the same county hospital. From a superficial perspective, and read across the 
entirety of the narrative, there is an obvious employment of circularity and historical repetition evident here. But there is a structural consistency on display here also, as such circularity was a feature of what Joseph Slaughter terms "the idealist bildungsroman" ${ }^{12}$. For Slaughter such circularity had a politically conservative function, through which the narrative of development effected

[...] a common transformation of the narrative grammar of first-person Bildungsromane, in which the novel concludes where it began after bringing the past into conjunction with the present and the earlier protagonist self into correspondence with the later narrator self, producing the Bildungsheld as the narrator-protagonist (citizen-subject) of its story ${ }^{13}$.

Though Declan has been a midwife to Ireland's economic success, firmly representative of the assertive linear timelines of capitalist temporality, he has returned to the site of his youth. But Quinn does not offer any sense of consoling resolution to the protagonist. Such a manoeuvre by Quinn does not alter the exertions and impacts of Declan's life, but, rather, it re-introduces alternative temporal possibilities at the close of the narrative. The narrative does not permit a single temporal trajectory to succeed without question or qualification, but neither does it re-write recent Irish economic and social histories. From a structural perspective, then, repetition and recurrence are some of the key temporal notions. Yet as we read Declan's reflections at the close of the narrative, further temporal multiplicity is in evidence. And this is part of the narrative's self-conscious critique of its own form, and what differentiates it from the kinds of narratives alluded to above by Slaughter.

In the ensuing extract, Quinn, firstly, attends to Declan's sense of the accelerated way in which the events of his life have passed, and this reference to velocity is not entirely misplaced with respect to the temporal figurations associated with Declan and his business milieu in the novel. And immediately after this fleeting affective response to the apparent transience of life, Declan invokes another temporal regime: the habitual and routine functionalism of his previous hospital experience. In this brief passage, then, Quinn positions Declan Boyle within alternative temporal regimes, and, indeed, hints at the multiple ways in which one is subject to differential institutional temporal rhythms. As Declan reflects at length:

His adult life had merely been the blinking of an eye between that first long stay in hospital and now. He looked around; he felt like the same man who had been taken up and folded into the rhythms of this institution, rendered powerless, woken and told to sleep at appointed times, fed, measured, talked to, moved about, considered, and eventually dismissed to go back out into the world. He looked at Sinead dozing in the armchair. That was the difference. That was the proof. She anchored him outside all this. (p. 262)

12. Joseph R. Slaughter, "Enabling Fictions and Novel Subjects...", p. 1410.

13. Ibid., p. 1415. 
Tellingly at the end of this extract, Sinead is cast as an enduring temporal and spatial marker in the topography of Declan's life experience. The memorial elusiveness articulated at the beginning of this paragraph, together with the impersonal dynamics of the hospital's temporal rhythms are remedied by the consoling presence of his wife. And Sinead's emphatic and reassuring presence for Declan is, once again, rendered in specific stylistic and grammatical terms by Quinn. As we read the above extract, the evasiveness of recollection, the transience of the life-cycle, and the utilitarian temporal arrangements of the hospital take the form of longer, even meandering, sentences, whereas the definition of Sinead's presence in Declan's life is underscored by its articulation in short, assertive sentences.

And the narrative retreats to such a mode of expression as the novel reaches its conclusion below. We witness a reversion to a stylistic selection that is entirely germane to the politics of temporality and to the narrative's relationship with the conventions of the bildungsroman:

At the end of the ward he saw his wife and his daughter talking to a doctor. Sinead glanced in his direction. Issie too. Further back was a young man. Could that be Owen? Could he have succeeded in calling back from wherever he'd been? But it wasn't. The conversation was ending, and the two women began walking towards him. Issie said something to Sinead, but he couldn't make out what. The two women were now at his bed and looking at him, their independent eyes full of love and worry. They were here. (p. 262)

As we have noted, at the conclusion of the narrative Declan's voice is increasingly, and predominantly, rendered in clipped sentences, short clauses that variously express disorientation and lack, yet strive for the consoling presences of family and of intimacy. In these moments, and in both form and content, Declan Boyle struggles for definition and clarity in terms of his past and his present situation. In the extract above, he strikes us as a vulnerable and exposed character, dependent on the actions of others - his wife and his daughter. In addition, at an instant of uncertainty in the present, Declan reaches into the past and the narrative touches fleetingly beyond realism, before Declan corrects his vision and realises that the male figure at the end of the corridor is not his deceased son, Owen. Again, from a stylistic perspective, the pair of questions regarding Owen are answered resolutely with clipped clarity. But, significantly, at this point of resolution in the narrative, Declan retreats to a dependence on his family, and Owen briefly emerges from the past, together with the alternative temporal possibilities his life had embodied. In contrast, Sinead and Issie, characters that had been relegated from the capitalist teleologies that contoured so much of Declan's public and private lives, now return as consoling and affective presences. Thus, characters that had assumed figurative significance as representatives of marginal temporalities in Declan's life are given central narrative presence by Quinn at the close of the novel - a crucial authorial critique. In the end, Quinn also smuggles in another temporal resonance, as he aligns his own novel with a narrative that is significantly concerned with the advent of modern temporal regimes: Woolf s Mrs Dalloway. As Clarissa Dalloway enters her party, again at the close of Woolf s novel, Peter Walsh famously asks: "What 
is this terror? what is this ecstasy? he thought to himself. What is it that fills me with this extraordinary excitement? It is Clarissa, he said. For there she was" ${ }^{14}$. The final clause of Woolf's modernist text uncannily chimes with the abbreviated statement of presence that brings Mount Merrion to a close. This precise intertextual allusion registers the narrative's focus on the competing, and often contradictory, temporalities of capitalist modernity - though without collapsing the latter text and historical period into their predecessors.

Declan Boyle's initial career plans are not centred upon the pursuit of industrialisation in Ireland, as prior to his decisive visit to the Communist German Democratic Republic, Declan is a civil servant in the Department of Finance, a vocation that is met with scepticism by his father, James Boyle. As with his own eventual distance from his son Owen's disposition, Declan's selection of public service over private legal practice is met with cynicism by his father. Yet there is a sense in which the career to which Declan devotes most of his working life is more proximate to that of his father's wishes than the lifestyle chosen by Owen. And in one of Declan's early recollections from his hospital bed in Ardnabrayba, he recalls a striking conversation with his father about his own life choices. In yet another instance of cross-generational tension over the trajectories towards the future, James Boyle admits that he retained strong reservations about entering the legal profession, and did so on the insistence of his father. In this respect we see several layers of time coalesce in one memory. In fact, four generations of Irish men struggle, resist and make choices that are figuratively legible as the narrative's problematisation of historical fate, certainty and the inevitability of the present.

The familial historical revelation for Declan occurs in his father's car, and the collision of the past, the present and possible futures plays out as they drive around the city centre of Dublin. Tellingly, their journey is abruptly interrupted by "a horse-drawn cart [trying] to manoeuvre out of a laneway" (p. 18). As the two Boyles wait for the horse and cart to clear from their path, the narrative voice shifts to an omniscient commentary on the unfolding scene:

The saloon car idled as the rag-and-bone man once again led the two horses back, and then forward again, in an attempt to get the heavily loaded cart around a pile of rubble that builders had left on the corner. The horses were unhappy and reared their heads in protest, made nervous perhaps by the cars, still a rare enough thing in the late 1940s. The cart, like the man, seemed from another century, roughly used, bolts, rusting, the timber battered and worn. (p. 19)

At one level Quinn furnishes a succinct dichotomised vignette here, offering a micro-drama of emergent and residual temporal regimes. Though this is the 1940s and Ireland has not entered into any tangible form of social and economic modernisation, the set-piece resonates as part of the figurative economy deployed by Quinn in his examination of the politics of time in contemporary Ireland. From

14. Virginia Woolf, Mrs Dalloway [1925], Ware, Wordsworth Editions, 1996, p. 141. 
the interior of the modern vehicle, the young Declan Boyle surveys what he can only decipher as the detritus of a fading era. He regards the man, his cart and his horses as objects washed ashore from another historical epoch. And yet, Quinn seems to impress that they persist, the residual co-exists with the Boyle men as they wait impatiently to progress at speed. Though a fleeting memory of Declan Boyle, the rag-and-bone man anticipates, and intersects with, resistant, alternative temporalities that punctuate the core narrative of Declan Boyle's development. Indeed, the temperamental nature of the horses, their skittishness in the face of the Boyle car, is in stark contrast to the mechanised efficiency of the vehicle that confronts them. Though preceding the country's actual modernisation, the passage converges with Paul Virilio's account of the "cult of speed" that has come to saturate much of life in the late $20^{\text {th }}$ and $21^{\text {st }}$ centuries in the Global North. For Virilio,

The faster we go, the more we look ahead in anticipation and lose our lateral vision. Screens are like windshields in a car: with increased speed, we lose the sense of lateralization, which is an infirmity in our being in the world, its richness, its relief, its depth of field ${ }^{15}$.

As we shall see, Quinn poses questions about the absence of just such "lateral vision" in the Boyle family, and in Celtic Tiger Ireland, in the form of Declan's children, Issie and Owen. Yet, there is also the vantage-point of Sinead Boyle, whose "lateral vision" is emphatically obscured over the duration of her life as domesticated wife and mother.

\section{Frozen in time}

Quinn draws the opening chapter of the novel to a close with the suggestion of a highly resonant question. The question is never actually posed by a young Sinead Boyle, as she arrives to visit her future husband, Declan, in the new hospital in Ardnabrayba. Up to this juncture, Quinn has established the present of the narrative as 1959, Declan is a patient in hospital and the narrative recounts how Sinead and Declan first met, as well as furnishing details on the formative stages of their developing relationship. Given the symbolism of the newly constructed hospital facility and the expectant energies of the courting couple, the opening chapter gestures to the fecundity of the future at personal and national scales. Yet, as Sinead enters Declan's ward in the hospital, the chapter ends with a note of discord relayed to us from Declan's position as bedbound patient. As Sinead and Sister Imelda process towards Declan's bed there is a palpable tension between the two women. The religious nurse betrays her obvious distaste for Sinead, while Sinead exhibits but does not verbally express an irreverent vitality that is consummately summed up by her unarticulated question.

15. Paul Virilio, The Administration of Fear, Ames Hodges (trans.), Cambridge, The MIT Press, 2012, p. 36-37. 
On the last day of August, Declan slept after lunch, and when he woke he saw a young woman, not a nurse, entering the nurses' station at the top of the ward. From the back she seemed smartly dressed. [...] It was Sinead. She must have come from Spiddal. But how did she know he was here? There was an ironic tilt to her smile as she caught Declan's eye, whereas Sister Imelda's own expression made it clear that her good opinion of Declan did not stretch to any of his lady visitors. [...] Sinead stood at the foot of his bed looking at him as the head nurse retreated to the office. She had an amused expression on her face as if to ask, "What kind of country is this at all?" (p. 45-46)

Sinead's entry into the hospital ward in 1959 supplements the narrative symmetry alluded to earlier - she is also present in Declan's hospital ward decades later. But the fact of her presence is added to by the ways in which her presence is described by Quinn. Sinead's appearance here is unexpected and unannounced, but Quinn uses the uncertainty of her arrival to mirror Declan's later "vision" of his dead son Owen at the end of the novel. Not only are Declan and Sinead together in hospital rooms as we enter and exit the narrative, we get a sense of confused misrecognition on Declan's part. In each case this is clarified, but it offers us a glimpse into the narrative's political motivations and messages; the solid certainties of linear progress and transparent reality are consistently problematised across Mount Merrion. Indeed, this is where the significance of Sinead's unposed question comes into play. The question is never verbally articulated but remains as a physical figuration open to interpretation, and it embodies the capacity and the willingness of the youthful Sinead to trouble the certainties of such Irish institutions. In retrospect, the openness of the unexpressed question links Sinead to her future children, Issie and Owen, both of whom chafe against but never conclusively overcome the breed of liberal capitalist society to which Declan contributed and cleaved. Though prompted by the immediate context of moral censure embodied by Sister Imelda, in the broader historical context, Sinead's facial figuration might well be posed at the close of the narrative on foot of the scandalous revelations regarding property development and political corruption that mark Declan Boyle's professional decline. Finally, Sinead's physicality is telescoped in this set-piece as she is "seen" as "smartly dressed" in the first instance by Declan, while subsequently the narrative refers to the "ironic tilt to her smile", as well as the concluding facial expression. There is an aggregation of ambiguity and suggestive playfulness to the ways in which Sinead's entrance and presence are established. The imaginative possibilities embodied by the irony of Sinead's smile work in a similar way to the figurative ambiguity of her facial expression - both are visions of the future in somatic form. At a grammatical level, the conjunction "as if" foregrounds the aforementioned ambiguity but also inaugurates a subversive dialogic and interpretive relationship with the viewer, Declan, her future husband. The headline future detailed across the chapter and the majority of the novel is that mapped by Declan Boyle - a future of economic and social modernisation that has the Celtic Tiger as its apotheosis. But, as with our discussions of Owen and Issie, Quinn's narrative is seeded with more or less subtle resistant expressions of alternative futures, and for Sinead her vision is expressed in these physical gestures in 1959. Unfortunately, for Sinead, that is where they both begin and end. 
If chapter one closes with the unexpressed, yet pregnant question, the title of chapter two, "Confinement", set in 1968, offers an unambiguous answer to Sinead as she finds herself "embalmed in respectability" (p. 53). The intimations, and expectations, of full-blooded possibilities for her future that emanated from Sinead's physical presence in the first chapter of the novel are still-born a decade later - as Quinn's apt metaphor above underscores. Apart from the rote operations of marriage and recent motherhood, Sinead's life is denuded of stimulation and sensation. The ironic contour of her smile no longer reaches out to a willing recipient, rather she finds herself isolated by her "confinement" within middle-class respectability. Yet, as Quinn outlines, the wit, the intelligence, in other words, the sources of her erstwhile ironic take on institutional and social conformity is not dormant. And, of course, this is the cause of so many of Sinead's frustrations and difficulties over the duration of the narrative.

It was not until the awful early fog of new motherhood had dispersed that Sinead started to understand that something was wrong. She longed for company during the slow suburban days, preferably that of another woman who had also had a child and had some idea of the feelings coursing through her body. She ached to pour out her thoughts and have somebody receive them and help her make sense of them. The bubbling water in the central heating, the call of birds outside and a very occasional car or delivery van moving through the estate: this was what passed for silence in suburbia. These were the sounds that came forth when there was no one else there to divert your attention. (p. 53)

If the irony of Sinead's smile a decade earlier was directed at, and received by Declan, the exertions of motherhood and domesticity have left her devoid of a capacity for and outlet for communication. The idiom here remains focused on Sinead's body, but now instead of the minor subversion of a facial expression, the bodily imagery expresses her profound feelings of entrapment and isolation. The sensory experiences of suburban Dublin are rendered in sibilant poetic form by Quinn, yet what they detail are not remotely satiating for Sinead. The ironic smile of her youth may have been a silent somatic signal but Sinead now finds herself cocooned in a suburban silence that is evacuated of all of the imagination and hope of her student life.

Having spent a period of time living in Ardnabrayba establishing one of Declan's initial industrial projects, the Boyle family return to suburban Dublin in chapter 4, “The Royal Marine, 1974-5". The children are now at school and Sinead's days are only punctuated by the routines dictated by Issie's and Owen's requirements. In this context Sinead's sense of domestic emptiness returns and she retreats, firstly, into a functional alcoholism, which progresses and necessitates treatment for addiction. At the outset of her dependence, Sinead shares a glass of wine with other mothers, but gradually any sense of the sociality of her drinking is lost and it becomes a means through which she effectively disappears from significant aspects of the household's life:

At some point, Sinead realized with happiness that she didn't really need to the excuse of Jackie or Bronagh in order to open a bottle in the afternoon and drink it all. She would 
hash up some kind of dinner and retire to bed while the children ate in the kitchen. Declan would often find her asleep when he got home from work, and this left him free to stay up late with his papers in the study. (p. 125-126)

Thus, this is not merely a portrait of suburban domestic loneliness, but the household is also rendered as fragmented; its residents occupy different spaces and different times. Sinead's retreat into alcoholism, though unknown to Declan at this juncture, affords him the freedom to sunder the boundaries between work-time and home-time. While Sinead herself abdicates much of her agency within the daily routines of the family's timetable; the action described above reveals a capacity and a willingness just to perform the minimum required. In another respect Sinead's alcohol-fuelled absence here is facilitated by a combination of Declan's complacency and rigidity. He complacently assumes, and rigidly believes, that the domestic duties and dramas are his wife's sphere. Still further, from a temporal perspective, the productive time that Declan is afforded both inside and outside the home is effectively purloined from his wife. As she expresses at several points elsewhere in the narrative, there is now little or no prospect of her pursuing a career given the amount of her time that has been devoted to their family and their home. By no means exceptional by the standards of her generation of Irish women, Sinead's experience, and the various ways in which she expresses frustration and disquiet about that experience, are wedded to the more explicit critiques of teleological narratives of capitalist modernity represented by the lives of her two children. As we have seen above, the needs of the Boyle children and Sinead are subservient to the demands of Declan's burgeoning career. This career trajectory appears to be imbued with a sense of the inevitable and the inviolable; there is an assumed logic to the form and the content of Declan's professional life that chimes with the temporal logic of capitalist modernisation. Once more, any residual sense of future-oriented vitality and agency that might have marked Sinead's youth is reduced to the limits of a series of regular gendered social and domestic performances as Declan's wife. It is not just the mundane silence of middle-class suburbia that characterises her life, but there is also the conclusive silencing of her erstwhile hopes and ambitions.

In due course, Sinead's alcoholism reaches a serious stage that impacts directly on her children and which requires intervention. In a telling passage that again reveals the silent yet clear articulacy of non-verbal expression, Quinn reveals the tragic circumstances under which Sinead is finally allowed to tell a version of her story:

When she called out to him cheerfully from the kitchen, she saw the transformation in his face as delight came over it - delight at the fact that she was not in the living room with the curtains closed, lying on the couch drunk, with the world, including him, gone dark in front of her eyes. Many years later, after she'd attended hundreds of meetings like the one that lay ahead of her that day, she would tell this story. How she'd watched her son come in the door. How she'd seen the fear in his eyes. How she knew that she'd created that fear. How she then knew she was an alcoholic and that she would never touch a drink again. (p. 136) 
The contrasting emotions expressed on Owen's face in this sequence actually take place in reverse order to the way in which they are relayed here, as Quinn invokes a series of temporal markers. Most explicit in this respect, is the fact that there is an inescapable symmetry to the use of facial expression by Quinn as a means of uniting the mother and son in the broader figurative and ethical patternings of the narrative. Likewise, Owen's face beams with "delight" at the absence of his mother in an endarkened living room; it is the non-presence of a drunken mother that transforms his expression in as much as it is the sight of a sober Sinead in the kitchen. In his expectation of being met by his drunken mother once more there is a sense also that Sinead haunts the familial home, that she is a faded version of the younger Sinead and that she is out of kilter with the expectations of her society. And it is this latter point that precisely links both mother and son. Neither is entirely content with, and content to inhabit, the roles they have had assigned to them under the auspices of Declan's worldview. This compressed focus on the temporal is overt in the proleptic preface to Sinead's moment of self-expression and self-reflection that brings the passage to its close. This sentence performs as a temporal pivot and as a linguistic pivot - these thoughts are expressed by a future Sinead and they are expressed in a more measured staccato fashion than the opening lines of the extract. From a temporal perspective we are exposed to a future Sinead that feels redeemed who inhabits a future that is qualitatively different to the functional teleology of her husband. We get an impression of the labour invested in her recovery and she reveals that the intensity of this labour is geared towards and motivated by the emotional needs of her son. Quinn figures Sinead's investment in her recovery in his anaphoric repetition of "How" at the beginning of the final four, relatively short sentences, thereby importing a technique that mirrors the step-wise approach of addiction recovery. But on closer examination we can also divine further insight into Sinead's progress across the four sentences. In the first two she is referred to as "watching" and "seeing"; while in the next two sentences the fact that she "knew" is repeated twice. The step-wise method of the anaphoric form works with the developmental move from recognition to conclusive understanding and acceptance. Akin to our discussions of Owen and Issie below, though less substantial in many ways and with less scope for potential change, the future detailed here by Sinead is remarkable in the context of the novel and our argument for the ways in which it is rooted in the personal and the affective. While it retains a temporally progressive form, it is laced with empathy, its yields are emotional and it is minted from a different value system to that which ultimately endures in Ireland.

\section{Haunting the "boom"}

Through a combination of his youthful death and his temperament, Owen Boyle represents a ghostly figurative alternative to the seemingly unassailable temporal dynamics of his father's Ireland. As Avery F. Gordon persuasively suggests: 
"Haunting raises specters, and it alters the experience of being in time, the way we separate the past, the present, and the future" ${ }^{16}$. Quinn's narrative enacts such a complication of the politics of time through the relative figurative significances of members of the Boyle family. The importance of Gordon's work for our interrogation of Quinn's narrative in terms of its critique of the Celtic Tiger and its problematisation of the bildungsroman rests on the manner in which Gordon underscores the critical valences of haunting. Acknowledging the Marxist heritage of materialist deployments of "haunting", Gordon frames her work in the following manner:

Ghostly Matters does attempt to describe, in homage to the viability of a Marxist concept of haunting, the ghostly haunt as a form of social figuration that treats as a major problem the reduction of individuals "to a mere sequence of instantaneous experiences which leave no trace, or rather whose trace is hated as irrational, superfluous, and 'overtaken"' 17 .

The latter quotation is taken from the "Notes and Drafts" section of Adorno and Horkheimer's Dialectic of Enlightenment, where the authors reflect upon the effective assault on the past by capitalist modernity, an assault that conditions a schismatic relation between the living and the dead. The provocation of a dichotomous relationship between the living and the dead is a fraction of the pacification of the present. Alternatively, for Adorno and Horkheimer:

Only the conscious horror of destruction creates the correct relationship with the dead: unity with them because we, like them, are the victims of the same condition and the same disappointed hope ${ }^{18}$.

The amnesiac condition of the modern subject under capitalism lives in an antagonistic relation with the past, and with the anachronistic that does not display functional and productive capacities. History is bleached from the consciousness of the modern subject "out of a fear that it might remind the individual of the degeneration of his own existence [...]" ${ }^{19}$. The dead and the past, in Adorno and Horkheimer's view, are bereft of profitability and utility in the modern context, and, consequently, have little or no "market value". And it is at this juncture that their note on ghosts, as well as its legacies in Gordon's work, bear on our elucidation of haunting and "living on" in Quinn's Mount Merrion, when they propose that:

The respect for something which has no market value and runs contrary to all feelings is experienced most sharply by the person in mourning, in whose case not even the psychological restoration of labor power is possible ${ }^{20}$.

16. Avery F. Gordon, Ghostly Matters: Haunting and the Sociological Imagination [1997], Minneapolis, University of Minnesota Press, 2008, p. xvi.

17. Ibid., p. 20.

18. Theodor W. Adorno, Max Horkheimer, "On the Theory of Ghosts", in Dialectic of Enlightenment, New York, Continuum, 1972, p. 215.

19. Ibid., p. 216.

20. Ibid. 
In contrast to the future-oriented and solidly materialistic characterisation of his father, Owen Boyle frustrates the linear teleology so formative of Declan's life and career. Though the superficial indices of continuity mark Owen's childhood and early adolescence, in particular his attendance at Deerpark - a private south Dublin school, he is temperamentally resistant to the ambitiousness of his father. On an evening socialising together, Sinead and Declan Boyle briefly reflect upon their two children, Owen and Issie, and it becomes clear that both children represent a set of alternative future possibilities. Declan reminds Sinead that Owen's school rugby career is flourishing, and then he privately muses:

He normally had no great interest in rugby, but he'd experienced a moment of exaltation the first time he saw his son score a try by virtue of talent alone [...]. He was obviously a talent, but Declan knew that he frustrated the trainers by his lack of application. They were irked also by the knowledge that if they'd dropped him, Owen probably wouldn't mind. Not that he was apathetic; it was more that he was extraordinarily equable. They had no power over him. (p. 141-142)

In differentiating between Quinn's use of Declan and Owen Boyle, we are not intimating that there is any internal animus between the characters within the narrative itself. Rather, as is made plain in the extract here, the linear instrumentalism of Declan Boyle's economic career is in marked contradistinction to the "equable" disposition of his son. Rugby is a suitable conceit at this point given the innate and intractable contestatory nature of the sporting arena. Not only is the openly competitive nature of the sport useful for Quinn's figuration, beyond the metaphoric we can also read the sporting contest as a further site on which competing temporalities are "played out". Owen's sanguine nature works against the grain of the primary teleology of the sporting contest, and while in this instance this does not create any undue tension between father and son, it is an embedded alternative temporal disposition seeded within Quinn's authorial critique of temporal and narrative linearity. Of particular note in this extract are the facts that Owen appears to exist outside of, or parallel to, the demands and the expectations of the various contexts in which he circulates. There is a sense of empowered coevalness to Owen's navigation of the increasingly competitive and teleogically rigid milieu of south Dublin.

Owen's death is reported abruptly at the beginning of chapter 5 in 1987, and it occurs on the night on which his sister, Issie's, Leaving Certificate examinations conclude. For the purposes of our argument, the end of Issie's night of celebrations with her school friends is utilised by Quinn as a further way in which to spotlight the centrality of time to his engagement with the histories and narratives of Celtic Tiger Ireland. As Issie and her friend Aideen return home, their attention is drawn to the sound of an approaching car:

Down at the bottom of the avenue, about half a mile away, a car pulled off the Rock Road and swung towards them. They couldn't hear the gear changes, but they watched the speeding vehicle, mesmerized by the headlights, until suddenly in a rush of noise it zoomed past towards Stillorgan, becoming a ghost. (p. 150) 
This description immediately precedes a visit by the police reporting Owen's death in a late-night car crash, but does not guarantee that Owen was actually in this specific vehicle. However, within the context of our discussion, the extract above is telling for at least two reasons. Firstly, and most obviously, Quinn appropriates a conventional Gothic figuration in referring to the ghostly qualities of the departing car. Indeed it is noteworthy that Quinn does not revert to simile here, rather the vehicle's metamorphosis into metaphor is still in process before the eyes of the two young watchers. But the metaphoric selection is more significant once we address its temporal connotations and associations, as it clearly performs a premonitory function in this instance. The very nature of the metaphor of ghostliness is, of course, connected to our concern with the disruption of normative temporalities, as the haunting figure of the ghost is traditionally "out of time" - its effectiveness at least, in part, accruing from this very temporal disjunctiveness. And equally the nature of premonition is akin to such subversions of linear, normative temporality - the roaring engine of the departing car is, then, a resonant note of forewarning from the future, albeit a future devoid of the equable disposition and creative possibilities of Owen Boyle. Yet Owen's death occurs in the narrative's past, consequently it is not just that the future is affected by his sudden death, but the past is altered. Owen's death, thus, signals an elongated continuum of lost possibilities, as the series of presents that eventuate in the past after his death are devoid of the informing agency of his temperament. Once again, as we saw above, descriptions of and reflections upon Owen emphasise his difference, and his temperamental divergence from those committed to linear teleologies. The distant car, heard careering in the present, is figured in terms of both the past and the future - the ghost has yet to be rendered as such in personal terms. Yet, there is the possibility that Owen, even in life, embodies unrealised possibilities from the past, as his temperament is a correlative of social and dispositional alternatives to the burgeoning equivalents of neo-liberal capitalism. Owen Boyle's life, and the possibilities associated with that unlived future, are clearly cut short, remaining unfulfilled, and from a formal perspective in terms of Quinn's engagement with the bildungsroman, he represents "the perpetuation of adolescence [which] displaces the plot of growth; the inability to make a fortune or stabilize an adult ego displaces the fulfilled vocational and sexual destiny" ${ }^{21}$.

Ultimately Owen pursues a career waiting tables in the Pot de Vin, before moving out of his parents' home. And again, Declan's thoughts on Owen's choices and actions underscore the gaps that existed between father and son:

Before Christmas, Owen moved out to a flat in Northumberland Road, to share with two of his fellow waiters. He was, Declan knew, putting distance between himself and Mount Merrion Avenue, and all that the place represented. [...] Now, as he observed the stricken face of John Finnegan, Declan understood that what he'd hoped was a

21. Jed Esty, Unseasonable Youth: Modernism, Colonialism, and the Fiction of Development, Oxford, Oxford University Press, 2012, p. 15. 
passing fancy had become a way of life for Owen. He'd never resat the Leaving Cert, never gone to university, never moved back home. (p. 156)

Just as Quinn shuttles between the literal and the metaphorical above, Declan does so here, as Owen's relationship with his material and cultural inheritances are alluded to by his grieving father. Quinn condenses Owen's, and by implication through metonymic figuration, his authorial misgivings about the roots of, and contemporary iterations of, these materialistic teleologies into the representative space of Mount Merrion Avenue. This site of wealth serves as a temporal and spatial figuration for the triplet of absences and incompletions with which this extract concludes, and that score Owen's divergence from the vectors of social conformity in Celtic Tiger Ireland. The politics of space and time of the emergence of and the contemporary reality of the Celtic Tiger are the primary focus of the novel, yet the narrative also addresses other implicated and informative political and cultural conceptions of space and time. Tellingly, we cannot forget that these paternal reflections occur at Owen's funeral and, thereby, assume a haunting quality. Indeed, as we encounter Declan's memories of his son here, and re-read them in relation to the close of the novel - where an apparition of Owen is mistakenly hinted at by Declan - the full figurative potential of Owen Boyle is legible in terms of Gordon's writings on the persistence of unrealised potentials and social haunting. Owen Boyle dies quite early in life, and a little after the midpoint of the novel, but through the circularity of its narrative structure and by the ghostly return made by Owen in his father's mind at the close of the narrative, Quinn affirms the validity and vitality of multiple unrealised temporalities. As Gordon argues "[f]ollowing the ghosts is about making a contact that changes you and refashions the social relations in which you are located" 22 . It would be reductive to posit that Owen Boyle is the solitary "ghost" that haunts Mount Merrion, rather, as Gordon would contend, he is representative of the plethora of alternative socio-economic and cultural possibilities that have been nominated as having "failed", and that have been superseded because of inefficiency, or lack of productivity within the calculating frames of capitalist modernity.

\section{Daughter of progress}

Issie Boyle assumes a similar function in the narrative to her younger brother. Quinn draws our attention to the spaces and contexts to which Issie is drawn, and, also, to the language through which she is described. The former locations are at least partially contradictory of the kinds of spatial imaginaries valued within the calculus of the Celtic Tiger economy, and that preoccupy her father. Issie's proficiency with language, her aptitude for and interest in literary art, and the sensuousness of the language used to evoke her character and temperament are

22. Avery F. Gordon, Ghostly Matters..., p. 22. 
signs of an alternative creative register within the novel. Though Quinn does not present us with a radical counter-narrative, or with a coherent subversive vision, of Celtic Tiger Ireland, in tandem with the still-born future possibilities of her brother, Owen, Issie Boyle also represents an alternative form of futurity. In other words, akin to her deceased brother, she intimates at a divergent temporal track to the one dominant in Celtic Tiger Ireland. Issie is born in 1968, a decisive year in the economic and business plans of her father, who, on foot of a diplomatic visit to the Communist German Democratic Republic, formulates a strategy to establish a factory in Ireland. This will be done with the aid of an East German colleague, Rolf Portsch, who will defect with his family on a flight with Declan. The flight lands in Dublin on the day of Issie's birth, and Declan's first and only response to his daughter's arrival is revealing:

His daughter: As the nurse withdrew her fingers from under the head and back, and she nestled fully in the crook of Declan's arm, it came home to him with full force: there was another woman in his life, when he still hadn't got used to the fact of Sinead. (p. 109)

Issie is almost crowded out of the narrative as her entrance is shadowed on either side, firstly, by Declan's Cold War interlude that precedes her entrance, and the immediate description of his subsequent devotion to his new business venture. Though partly couched in initial tenderness and pride, the content of the preceding passage is plainly suggestive of innate distance. Both the immediate moment in which he responds to his first-born child, and her difference, as well as the frenetic national and international commercial activity are markers of Declan's remoteness from his wife and daughter across significant sections of his life and of the narrative of Mount Merrion. In another way, it is as if Issie is a conundrum to be resolved. Her sheer presence and her naked existence appear as challenges to Declan, though they are rarely given the attention they warrant. Indeed, his incomprehension resonates with the fact that Issie ultimately emigrates, and not to a typically secure economic location with certain employment prospects. Her birth is marked by her father's return from East Germany with a fully-fledged capitalist vision, which anticipates, and is later mirrored by, her emigration to the same country but under, and to, vastly different circumstances. Declan's journey is a form of captivity narrative, as he liberates Rolf Portsch from the temporal and spatial anteriority of the Communist German Democratic Republic, while Issie's reverse journey is a retreat from the emergent consumerism of Celtic Tiger Ireland. Yet, as we know, Issie's is not a narrative of triumphant alterity, nor can it be considered entirely conformist in the end. Quinn cannot permit Issie to escape from her father's narrative, as, in the end, this is the basis of the novel's historical critique.

After the cursory note detailing his daughter's arrival, in the next paragraph the narrative moves abruptly to Declan's professional preoccupations:

The following weeks were the busiest of Declan's life. He took some days off, but spent most of the time on the phone. Mick Guilfoyle TD rang to warmly congratulate Declan on the birth of his daughter. He also said he thought the factory was a great idea, and 
he fully agreed with Declan that it should be built in the vicinity of Ardnabrayba. The area needed it, he said. Declan found the man likeable, and couldn't square the voice on the line with the ruthless character of Sean Guilfoyle's story. (p. 109)

This extract is revealing in a number of respects, and it alights upon a selection of the key concerns germane to our argument. First of all, the key temporal trajectory of the emerging Ireland is signalled in the opening clause of the first sentence - an extended period of time is compressed into one brief sentence, and this has little to do with Declan's devotion to his newly born daughter or recovering wife. The pressures of the imminent and expectant future of Ireland's economy take immediate precedence, and this takes manifest form in the burgeoning relationship between the respective political and economic agents. But one of the possibilities afforded Quinn in his composition of an historical narrative is hindsight. As readers we are alert to the tragic irony of Declan's apparent innocence regarding the bona fides of his political collaborator, the full import of which only becomes apparent at the close of the novel. In much the same way that Declan assumes metonymic significance within the narrative, Mick Guilfoyle is cast in an equivalent role by Quinn. Ardnabrayba is not only Guilfoyle's local constituency, but it is also Declan's family's original home-place. This confluence of economic and political interests is part of the broader spatial patterning of Mount Merrion wherein the local, the national and the global become necessarily intertwined. Of course, the manner in which this teleology is foregrounded at this specific juncture in the narrative is just as significant for what it occludes. As we have asserted, these present and future plans obscure Issie's birth and its immediate aftermath. In other words, at this point of origins and beginnings, one linear and, seemingly, unproblematic temporal compact, or contract, erases the possibilities of another.

Such temporal and narrative autocracy is not confined to Declan's occlusion of his daughter's birth from his vision of the future in the extracts highlighted above. Elsewhere they are apparent in his attempts to adhere to the formative narrative contours of a particular breed of national identity. Issie is not the only female character whose future is simultaneously dictated and discarded by the narrative priorities of Declan's "Ireland", the same is true of her mother, Sinead. Where the three combine is in the decision regarding the selection of Issie's secondary school. On the surface the contentiousness of the conversation between Declan and Sinead is unsurprising, and is legible as another occasion of patriarchal assertion within the Boyle household. Yet, just as Declan's future vision at the moment of Issie's birth focuses upon the viability and the establishment of an economic opportunity, erasing altogether the futures represented by his daughter's arrival, Sinead's reflection here represents an altogether different disposition towards her daughter's future. From Sinead's current vantage point her education offered little other than a preparatory ground for acquiescence to, and subservience to, a normative narrative of marital passivity.

She had tried to argue against sending Issie to Roebuck, where the nuns had taught her and her fellow students that their accomplishments in life must be merely adornments 
to their lucky husbands. Declan answered that there was no other good girls' school in the vicinity. [...] He came back to her with reasons she couldn't now recollect - something to do with university places or the like - but she knew he wanted the children to go to a Catholic school, in the traditional way, without the distraction of the opposite sex. In so many respects Declan was impatient with the past, but on this he was immovable. (p. 123)

As we note from Sinead's experience of her marriage, it is a form of confinement in physical and imaginative terms. Obviously, Sinead's critique of her convent education is far removed from the violent excesses uncovered during the Celtic Tiger period in Ireland, but there are clear political and economic consequences for this kind of pedagogical practice. In a sense, the narrative possibilities outlined by both "the nuns" and, in turn, by Declan are in alignment. Though qualitatively different, both impress the need to adhere to a stable and self-perpetuating educational system, under which women such as Issie and Sinead remain subservient to the needs and the demands of the broader economic and political narratives. But the coalescence of a traditional Catholicism and Declan's impatient drive towards the future is in no way self-contradictory. In terms of our discussion it re-enforces the notion that multiple temporalities co-exist and persist at a given historical moment. Put simply, Declan's aggregated modern secularism and traditional moral Catholicism echo the alternative imaginative and temporal possibilities represented in the novel by his two children.

\section{Conclusion}

In combination, then, our review of the significances of the temporal figuration of the Boyle children chimes with Gregory Castle's reading of the work of the Algerian writer Assia Djebar. Analysing Djebar's work in terms of what he dubs, the postcolonial bildungsroman, Castle suggests that

She also draws on what can be called failing time, the temporality of not having become, of recalcitrance and abstention, of fluid, recursive, multiple, and simultaneous potentialities whose very excess militates against a determinate chronology or telos ${ }^{23}$.

Castle's notion of "failing time" should not be exported unproblematically across these discrepant contexts. Nevertheless, the ways in which Declan and Sinead Boyle's children are portrayed and figured across the narrative are consistent with the relegation of alternative temporalities, as indicated by Castle. Indeed, though concentrating on divergent time periods and geographies, Esty's work on the resistant facets of modernist narratives of "unseasonable youth" resonates with both Castle's reading of Djebar's temporal frames, as well as our elaboration of the

23. Gregory Castle, "My Self, My Other: Modernism and Postcolonial Bildung in Assia Djebar's Algerian Quartet”, Modern Fiction Studies, vol. 59, no. 3, 2013, p. 633. 
temporal multiplicities evident across Mount Merrion. Quinn's narrative is patently a critique of the ease and alacrity with which progressivist modes of temporality assumed precedence in Ireland. However, despite Mount Merrion's attentiveness to the dominant social, economic and political agencies and personalities that fully subscribed to the logic of globalised capitalism, there are moments of unrealised hope and alternative routes seeded within the narrative. The implication is, of course, that such temporal multiplicities exist at any historical juncture, and even when not recognised or realised, they are still present in times of crisis. In these respects, Quinn's concentration of overlapping and competing temporal visions is as much a critique of the deleterious effects of adherence to one linear form, as it is a prompt to acknowledge and to prospect for alternative temporal visions in the contemporary moment.

Potentially more utopian in its implications is Castle's second interpretation of Djebar's temporal vision. In addition to repetition he posits the political traction of her attention to the notion of a gendered "eternal" time evident in "writing that seeks to transcend conventional temporal demarcations and limits" ${ }^{24}$. In this context we might productively draw an analogy between Castle's reading of Djebar and Quinn's figuration of Owen Boyle as symbolic of a form of "eternity". In life, Owen evades the assertive, wilful linear functionalist temporalities of his father and of his rugby coaches via his equable temperament. Yet, in the light of Castle's allusion to the "eternal", we might also suggest that Owen's death might be retrieved from its tragic circumstances and effects by reading it as a continuation of his earlier evasion of oppressive and autocratic temporal regimes. Taken at a figurative level, the potentialities and validity of Owen's attitude to productive time do not wither with his death. Instead the insistent memory of these alternatives remains germane to the narrative as it progresses after his departure. And, equally, they remain part of Quinn's authorial critique of Ireland's contemporary history, and of the temporal logic most dominant across that history. Ultimately, Quinn's deployment of both Boyle children in relation to the politics of time is consistent with a resolute scepticism regarding the modes and accruals of, what David Lloyd terms, "developmental historicism" 25 . As we have noted, in his study of narratives of "unseasonable youth", Esty illuminates a suite of novels wherein such a naturalised plot of development is frustrated or problematised ${ }^{26}$. Esty's work focuses on "the perpetuation of adolescence" and how such a temporal manoeuvre "displaces the plot of growth" so structurally integral to the bildungsroman ${ }^{27}$. Often adhering to an allegorical format, the bildungsroman retains a conventional temporal framework, as the telos of individual and national development mirror one another. In Quinn's employment of the bildungsroman form, and its allegorical and temporal features, we can identify youthful characters that defy the allegorical form and

\footnotetext{
24. Gregory Castle, “My Self, My Other...”, p. 634.

25. David Lloyd, Irish Times: Temporalities of Modernity, Dublin, Field Day, 2008, p. 75.

26. Jed Esty, Unseasonable Youth..., p. 18.

27. Ibid., p. 15.
} 
temporal trajectories of the generic conventions of the bildungsroman ${ }^{28}$. Quinn's generic selection is an entirely apt critical-creative mode with which to confront and to reflect upon the narratives of fate and inevitability that frequently attached themselves to celebrations of Ireland's economic "miracle".

Eóin FlanNery

Mary Immaculate College, University of Limerick

28. Ibid., p. 17 and p. 24. 